\title{
Tourism destination image as an antecedent of destination loyalty: The case of Linz, Austria
}

\author{
Elitza lordanova ${ }^{1 *}$
}

Received: 11/07/2016 Accepted: 03/11/2016

\begin{abstract}
1 Senior Lecturer in Tourism and Aviation, School of Management and Professional Studies, Buckinghamshire New University, High Wycombe Campus, Queen Alexandra Road, High Wycombe Buckinghamshire, HP11 2JZ; E-mail: elitza.iordanova@bucks.ac.uk

* Corresponding author
\end{abstract}

\begin{abstract}
The concepts of destination image and tourists' loyalty are sufficiently discussed in the literature; however, due to the multi-dimensional character of these two concepts, the existing studies fail to shed light on the multifaceted linkage between destination image and loyalty. This research displays an innovative way of measuring tourists' loyalty by creating a composite loyalty index that represents both behavioural and attitudinal loyalty. The index allows for a distinction between different levels of tourists loyalty to be made in order to establish the impact of both cognitive and affective destination image dimensions on loyalty. The findings reveal that the better the image, the higher the composite loyalty. Specifically, destination's affective image is more influential on tourists' loyalty than destination's cognitive image.
\end{abstract}

(C) 2017 Varna University of Management. All rights reserved

Keywords: destination image, destination composite loyalty, behavioral loyalty, attitudinal loyalty

Citation: lordanova, E. (2017) Tourism destination image as an antecedent of destination loyalty: The case of Linz, Austria. European Journal of Tourism Research 16, pp. 214-232

\section{Introduction}

Over the past decades, many small and medium sized towns believed to have found a "savior" in the form of tourism development as a major source of economic benefits, along with improved local communities' quality of life (Dumont et al., 2010). However, establishing a place as a competitive and attractive tourist destination on the highly overcrowded with popular tourism "bastilles" map is a demanding activity. In this competitive environment, visuality is seen as a key issue and destination marketers invest much effort and resources in creating an image that would establish a destination as attractive in tourists' minds (Dumont et al., 2010; Kneesel et al., 2010).

Loyalty in the tourism literature in general is linked to customers' repeat purchases or recommendations to friends and family and is argued to be a crucial element for the success and sustainability of any destination (Bodet, 2008; Korte, 1995; Lee, 2003).

Despite the fact that the process of eliciting the factors influencing revisit intentions is a 
challenging task, recognized as such by Woodside and Dubelaar (2002), Vassiliadis et al., (2013) and Chi \& Qu (2008), an extensive research has been carried out on this topic. The majority of studies mainly address the impact of visitors' satisfaction (Chi \& Qu, 2008; Mahasuweerachai \& Qu, 2011; Suhartanto et al., 2015; Sun et al., 2013; Yuksel et al., 2010); perceived quality or quality related constructs (Chen \& Gursoy, 2001; Sun et al., 2013), previous experience (Alegre \& Cladera, 2006), cultural dissimilarity (Chen \& Gursoy, 2001), and place attachment (Lee et al., 2007; Simpson \& Siquaw, 2008, Yuksel et al., 2010). Still, there are insufficient studies that adequately address the relationship between destination loyalty and other tourism-related constructs such as destination image (Assaker et al., 2011; Chang et al., 2015; Chen \& Phou 2013; Chi \& Qu, 2008; Lee et al., 2007; Ramseook-Munhurrun et al., 2015) despite its well-recognized influence on visitors' preferences as it is widely acknowledged in the tourism literature that travellers make their decisions based on the mental images they have of places (Cronch, 2011; Leisen, 2001; Stepchenkova \& Eales, 2011). The purpose of the present study, therefore, is to explore the relationship between two complex and multidimensional concepts - destination image and tourist loyalty - in order to provide further insights into this rather grey area of tourism research. The paper has the following objectives: 1) to compare and contrast the different types and nuances of tourist loyalty, 2) to design and implement a composite loyalty index consisting of both behavioural and attitudinal loyalty and 3) to explore the nature of the relationship between cognitive and affective destination image dimensions and visitors' composite loyalty.

The destination investigated in this research is Linz - the third biggest town in Austria situated astride the Danube River. Recently, the mixture of stable local economy, modern technology and culture has become the trademark of Linz (Lewonig, 2007), but despite Linz's diverse cultural life, the recently built museums for modern art (e.g. Lentos, Ars Electronica) and three big hallmark festivals (the "Cloud of Sound", the "International Street Artist Festival" and the "Ars Electronica Festival"), Linz is still staying in the shadow of Vienna and Salzburg. During the Nazi period, Linz was transformed from a small town into an industrial city with a potential to become a cultural metropolis on the Danube. After 1945 the main concern of Linz's authorities was to distance themselves from Nazi's culture and Hitler, in particular, while highlighting traditionally humanist cultural values (Cultural Development Plan, 2000). However, traces of Nazi's past are still part of everyday life in Linz - in the appearance of the so-called "Hitlerbauten" (cheap homes that Hitler built for industrial workers) and in the materials used for buildings construction that raise an embarrassing point: Mauthausen (a concentration camp close to Linz) granite was paid for with the lives of concentration camp prisoners (Linz European capital of culture, 2009, cited in lordanova-Krasteva et al., 2010).

\section{Conceptual Framework}

\section{Defining and Conceptualizing Destination} Image

Destination image is presented as a vital and influential factor in various conceptual frameworks elucidating the travellers' decision making process (Lee et al., 2005; Molina \& Esteban, 2006; Ramkissoon et al. 2011; Yüksel \& Akgül, 2007) since it is believed that travellers make their buying decisions based on the mental images they have of places (Cronch, 2011; Leisen, 2001; Stepchenkova \& Eales, 2011).

The multifaceted concept of image has been analysed from a variety of perspectives, where "different aspects are covered by different disciplines" (Rodrigues et al., 2011: 105) and in tourism studies, there is still a considerable diversity of definitions and conceptualizations of destination image. This observation would indicate that either there is a substantial level of uncertainty towards what constitutes tourism destination image and how it is formed amongst the researchers fascinated by this topic, or that destination image is so "multidimensional and complex" (Gallarza et al., 2002, p. 56) that can be explained by all these competing definitions.

Moreover, just recently tourism researchers started to perceive destination image as constantly evolving and to embrace its dynamic 
structure (Campo-Martınez et al., 2010; lordanova, 2015; Kim \& Morrison, 2005; Yüksel \& Akgül, 2007), while previously the majority of researchers used to define destination image as a static construct (Hunt, 1975; Chen \& Tsai, 2007; Bigne et al., 2001). This study allies with the former point of view and perceives destination image as a complex output of a process that requires various stimulus to occur. Therefore, Iordanova's definition (2015, p. 49) of destination image as "...a construct consisting of impressions, beliefs, ideas, expectations and feelings accumulated towards a place over time gathered from a variety of information sources and shaped through an individual's socio-demographic and psychological characteristics" was adopted as it appeared to be most appropriate for the purposes of this research.

Another inconsistency in the literature is linked to the construct of destination image. Some scholars recognize an internal, even though sometimes loose structure (Baloglu \& McCleary, 1999; Echtner \& Ritchie, 1991), whereas others (Crompton, 1979; Reilly 1990) support the idea that there is no recognized structure in destination Image and it should be approached as one inseparable whole. Consequently, Lai \& Li (2012) distinguished three different models of destination image within the stream of research - Baloglu \& McCleary's (1999) "cognitive-affective-overall model”, Gartner's (1993) "cognitive-affectiveconative model" and Echtner \& Ritchie's (1991) "three-dimensional model". In tourism studies, cognitive image components are linked to "...awareness, knowledge or beliefs, which may or may not have been derived from a previous visit" (Pike \& Ryan, 2004, p. 334) and memories, evaluations and interpretations and decisions (Tasci et al., 2007). Affective image components, on the other hand, are defined as "the appraisal of the affective quality of environments" (Hanyu, 1993, p. 161) or as emotional reactions, (excitement, pleasure, etc.) (Walmsley \& Young, 1998), responses (Pocock \& Hudson, 1978) and feelings towards tourist destinations (Russel, 1980).

There seems to be an agreement in the literature that destination image is a subjective interpretation of reality made by the tourists
(Bigne et al., 2001) and both cognitive and affective evaluations are equally important in the process of destination image formation (Beerli \& Martin, 2004; Kim \& Richardson, 2003). This point of view is supported by the increased amount of destination image studies focused on both cognitive and affective image components (Baloglu \& Love, 2005; Hosany et al., 2006; Hyun \& O'Keefe 2012; Kastenholz, 2004; Kim \& Perdue 2011; Pike, 2006; Pike \& Mason, 2011; Martin \& Bosque, 2008; Sonmez \& Sirakaya, 2002; Wang \& Hsu 2010).

The "cognitive- affective-conative model" proposed by Gartner (1993) and further tested by Chen \& Phou, (2013), Pike \& Ryan, (2004) and Tasci et al., (2007) supports a layered sequence in image formation, where cognitive image appears first, followed by its evaluative dimension and cognition, which represents the "decision stage" of image formation and depends on the cognitive and affective stages. In sharp contrast to the above discussed models is Echtner \& Ritchie's model (1991) as it depicts destination image as a combination of thee continua - attribute-holistic, functionalpsychological and unique features such as iconic events, feelings or auras.

This study supports the cognitive-affective composite nature of destination image and recognizes that while in everyday life, people do not resolve image into cognitive and affective components unless they are asked to do so (Baloglu \& Brinberg, 1997), from a theoretical point of view, the decomposition of image into cognitive and affective parts gives better understanding of its structure and supports in-depth statistical analyses (Bagozzi \& Burnkrant, 1985).

\section{Defining and Conceptualizing Tourist loyalty}

It has commonly been assumed in the marketing literature that consumer loyalty is linked to customers' repeat purchases or recommendations to friends and family (Chang \& Tseng, 2013; Floh et al., 2013). One of the prominent definitions of brand loyalty is provided by Oliver (1999, p. 34) and describes loyalty as "a deeply held commitment to re-buy or re-patronize a preferred product/service consistently in the future, thereby causing repetitive same-brand or same brand set purchasing, despite situational influences and 
marketing efforts having the potential to cause switching behaviour". A number of tourism studies borrowed the concept of customer loyalty from the general marketing literature and incorporated it into studies explaining travellers' loyalty towards tourism products, destinations and leisure/recreation activities (Backman \& Crompton, 1991; Baloglu, 2001; Iwasaki \& Havitz, 1998; Lee et al. 1997; Mazanec, 2000; Selin et al., 1988; Yoon \& Uysal, 2005) since loyalty is perceived as an issue of a major importance (Chen and Phou, 2013; Darnell \& Johnson, 2001; Lee, 2003) for the overcrowded and increasingly competitive tourism market. Loyal holidaymakers provide stable profit and reduced marketing costs as it is cheaper to retain existing customers than to target new markets (Eagles, 2001; Korte, 1995; Lee, 2003; Wong et al., 2014). Also, loyal visitors are considered to be less likely to switch to competitors regardless of the availability of comparable options (Wickham, 2000). Despite the fact that recent research not only suggests that identifying and satisfying consumers' needs might not be sufficient enough for a company to survive fierce competition (Carroll \& Ahuvia, 2006), but also gives evidence that having satisfied customers is not always equal to having loyal customers (Mittal \& Lasar, 1998) there are still insufficient studies on destination loyalty and its relations to other central constructs such as destination image (Assaker et al., 2011; Bigne et al., 2001; Chang et al., 2015; Chen \& Phou 2013; Ramseook-Munhurrun et al., 2015).

A major challenge in the literature on visitors' loyalty is the way of measuring it and it is often linked to the behavioural intentions of people who have visited a particular place in terms of their intention to revisit it or recommend it to others (Moore et al., 2013; Rodger et al., 2015; Tian-Cole et al., 2002; Weaver \& Lawton, 2011). For instance, Tian-Cole et al. (2002) and Weaver and Lawton (2011) relied on both the intention to revisit and to recommend the destination to other travellers in order to explore and measure visitors' loyalty. Tourists' recommendations about places they have visited is referred in the tourism literature as attitudinal loyalty (Correia Loureiro \& Miranda Gonzalez, 2008; Fournier, 1994; Hawkins et al., 1989; Lee et al., 2007, Li \& Petrick, 2008;
Mechinda et al., 2009; Opperman 2000; Yoon \& Uysal, 2005), whereas behavioural loyalty refers to tourists' behavioural outcome such as actual visits and repeat visits (Correia Loureiro \& Miranda Gonzalez, 2008; Lee et al., 2007; Li \& Petrick, 2008; Mechinda et al., 2009; Opperman 2000; Yoon \& Uysal, 2005). Even though only visit times should be used as a measurement of behavioural loyalty, there are studies arguing that repurchase intention is an indicator of behavioural loyalty as it is the prestage of actual repeat visits (Fan et al., 2009) and could be used to evaluate travellers' behavioural loyalty (Horng et al.,2011; Kaplanidou \& Gibson, 2010). An alternative view is the combination of the above discussed approaches, which presents customer loyalty as a multidimensional concept comprising of relative attitude and repeat purchase (Backman \& Crompton, 1991; Dick \& Basu, 1994; Iwaskaki \& Havitz, 1998; Oliver, 1999; Opperman 2000; Suhartanto et al., 2015). In tourism studies composite loyalty includes travellers' revisit intention and intention to recommend a place to fellow travellers (Baldinger \& Rubionson, 1996; Bowen 2001; Chen \& Tsai, 2007; Yoon \& Uysal, 2005). Nevertheless, there are still some studies that consider loyalty as either a one dimensional construct consisting of either intention to recommend (Chen \& Gursoy, 2001; Simpson \& Siquaw, 2008) or intention to revisit (Alegre \& Cladera, 2006; Alexandris et al., 2006; CampoMartinez et al., 2010; Jang \& Feng, 2007; Um et al., 2006).

Relationship between Destination image and Visitors' loyalty

The concepts of destination image and visitors' loyalty could be seen as having similar roots into the attitude theory proposed by Bagozzi (1992), which proves the importance of unravelling the complexity of the relationship between them. The attitude theory implies that appraisal could trigger emotions which, in turn, affect people's behaviour and also suggests that cognitive and affective reactions and behaviour happen in a consecutive order (Bagozzi, 1992). This argument finds support in Oliver's proposition $(1997,1999)$ that loyalty could be seen as a continuum of different levels of loyalty and the "cognitive-affectiveconative model" of destination image formation 
proposed by Gartner (1993) (discussed above) and tested by Chen \& Phou, (2013), Pike \& Ryan, (2004) and Tasci et al., (2007). The loyalty continuum starts with cognitive loyalty and goes through affective loyalty, conative loyalty and action loyalty. Cognitive loyalty is considered to be the weakest type of loyalty mainly formed based on the product information available to the customer (Pedersen \& Nysveen, 2001). Affective loyalty, on the other hand, is rooted in the consumers' minds and is less susceptive to changes (Oliver 1997, 1999). Conative loyalty, referred as consumers' behavioural intention to keep using the brand, is the strongest type of loyalty and the most robust one in terms of predicting behavioural loyalty (Pedersen \& Nysveen 2001). A few recent tourism studies (Yuksel et al., 2010; Forgas-Coll et al., 2012; Lee, 2014; Wong et al., 2014).) have adopted Oliver's proposition $(1997,1999)$ and depicted loyalty as consisting of cognitive, affective and conative elements. Still, albeit the partial research on this topic, there is some evidence that there is a relationship between destination image and tourist loyalty, but there is still no consensus regarding the nature of this relationship (Alcaniz et al., 2009; Bigné, et al., 2001; Bosque \& Martín, 2008; Castro et al., 2007; Chang et al., 2015; Chen \& Tsai, 2007; Chi \& Qu, 2008; Court \& Lupton, 1997; Faullant et al., 2008; Lee et al., 2008; Sun et al., 2013; Um et al., 2006; Mahasuweerachai \& Qu, 2011; Yoon \& Uysal, 2005). For example, some studies suggest that destination image directly affects tourist loyalty (Binh, 2015; Bosque \& Martín, 2008; Lee et al., 2008), or that the relationship is indirect (Castro et al., 2007; Chi \&Qu, 2008; Lee, 2009; Pandža Bajs, 2013; Ramseook-Munhurrun et al., 2015), whereas others argue that destination image has the ability to affect tourist loyalty directly or indirectly (Assaker et al., 2011; Bigné et al., 2001; Chen \& Tsai, 2007). These rather contradictory results could be due to the various ways destination image and loyalty could be conceptualized and operationalized. Indeed, a meta-analysis carried out by Zhang et al., (2014) on 66 articles in English and Chinese languages published in the last two decades on the proposed link between destination image and destination loyalty, revealed that out of the 66 articles, 23 measured tourists' attitudinal loyalty, 35 dealt with behavioural loyalty and 27 studied composite loyalty. However, the cognitive and affective image components are addressed in 5 of the articles focused on attitudinal loyalty (Lobato et al. 2006; Lin et al. 2007; Lee et al. 2008; Fang 2008; Qu et al. 2011), whereas only 8 articles discuss the link between behavioural loyalty and destination image (Baloglu, 2000; Lobato et al. 2006; Lee et al. 2008; Yang et al. 2009; Li et al. 2010; Fang 2008; Qu et al. 2011; Zhu 2011). Surprisingly, a very restricted amount of these studies (Nadeau et al. 2008; Hu, 2010; Shen, 2012) attempt to link the multidimensional concepts of both destination image and destination loyalty and to explain the link between both cognitive and affective components and composite loyalty, which mirrors the main aim of this research. This research, therefore, endeavours to contribute to the existing literature on visitors' loyalty and destination image by a) presenting an innovative method of measuring tourists' loyalty in the form of a composite loyalty index representing both revisit intentions (behavioural loyalty) and recommendation intentions (attitudinal loyalty) and b) by exploring the nature and the nuances of the relationship between cognitive and affective destination image dimensions and visitors' composite loyalty which still remains unclear until now.

\section{Methodology}

A critical evaluation of the existing literature on tourism destination image formation suggest that no single research method could elicit "the multidimensional, complex, relativistic and dynamic" (Gallarza et al., 2002, p. 56) nature of destination image and its determinants.

The research described in this paper is a sequential one - with second quantitative, explanatory phase building on a qualitative and exploratory first phase. The reason for collecting qualitative data initially originated from the fact that the image components existing in the literature are used, to a certain extent, in a unified manner and do not represent the spirit and auras of Linz. The selected research design was also influenced by Jenkins's (1999) model of destination image research. She argues that the use of qualitative 
research to elicit the constructs from the population being studied reduces the peril of pushing respondents to reply to a standardized framework, which might be a reflection of the destination image held by the researcher, but not by the population of interest. Even if there are similarities between destinations, the way of transferring a set of destination image dimensions from one destination to another without attaching importance to the unique features of a destination, results in simplistic and partial understanding of the process of destination image formation. Moreover, unless the list of attributes is thoroughly selected, some or even all of them might be completely irrelevant or there could be gaps in the list of destination image attributes (Jenkins, 1999). The advantages of using this mixed method approach were highlighted also by Echtner and Ritchie (2003) and O'Leary \& Deegan (2002).

Questionnaire design, sampling technique and data collection

\section{First phase}

The first phase of this study represented a qualitative exploration of Linz's image where Linz's image dimensions were elicited from the answers of a group of potential visitors (74), using an online survey with several openended questions and free elicitation technique. The term "potential visitor" is used as a cumulative portrait of repeat and first-time domestic and international visitors of Linz. It was assumed that selecting a sample of only one of the groups, for example first-time visitors or visitors who have previously requested information about Linz, would deprive the results by leading to missing important image components of Linz that could be captured only by individuals that had experienced the destination.

The utilized sampling technique at the first stage was convenience sampling since no population framework was available for the population of interest (potential visitors to Linz, Austria) and no cut-off date was predetermined, but at the same time the collected data was monitored and analysed on a weekly basis. After the first couple of weeks signs of repetition among respondents' answers started to slowly appear and after two months the online data collection was discontinued in view of the fact that it appeared to have reached its "saturation point" (see Maykut \& Morehouse, 1994; Kumar, 2005) or redundancy in regard to information where no new insights about Linz could be collected.

A series of open-ended questions based upon the questions used in Echtner \& Ritche's study (1993) together with a set of demographic questions was incorporated into the explorative, qualitative phase that aim to capture the image of Linz from visitors' perspective. The questions were slightly modified in order to fit the purposes of this particular research. The first question focused on respondents' spontaneous associations with Linz and was designed to allow respondents to freely share their overall spontaneous associations with Linz. The aim of the second question was to gain an insight into respondents' feelings and emotions in relation to Linz and attempted to capture the affective aspect of Linz's image. The final question sought to elicit respondents' knowledge of Linz and to determine some of its unique attractions.

The reason for eliciting the image components from the population of interest and not from official sources of Linz lies in the way the term image is used in the literature: a) the advertised and promoted image of a place and $b$ ) the beliefs and expectations of visitors (Mazanec \& Schweiger, 1981), which suggests that there might be significant differences between them. Linz's image was found to have been created through the mixture of Linz Nazi's past, the heavy industry, its well-preserved old town and architectural beauty; of the modern face of Linz presented by its museums for Modern Art (Ars Electronica Centre, the Lentos Museum), its hallmark events (The Cloud of Sound, The Bruckner Festival, The International Street Artist Festival), of the natural and eternal beauty of Postingberg and the River Danube. Linz was mainly described as a pleasurable, enjoyable, beautiful, admirable and modern place. The data collected from the first phase was then content analysed by identifying Linz's image elements and counting their frequencies of appearance in respondents' answers.

\section{Second phase}

The findings from the qualitative phase were used to construct a questionnaire, which was 
initially designed in English and piloted with 23 undergraduate students studying business, tourism and sport studies. The pilot study did not reveal any confusing and unclear questions or flops in its structure. The questionnaire was then translated into German and tested again with German native speakers.

The questionnaire was utilized to collect quantitative data from 400 visitors in Linz. To study Linz's image components elicited in the first phase, respondents were asked to rate their agreement/disagreement with those components on a 5-point Likert Scale ranging from "strongly agree" to "strongly disagree". Twenty nine cognitive evaluation items and fourteen affective items were generated from the first phase. Questions about intention to return and recommend a place to friends and/or relatives are considered as adequate to measure tourist loyalty towards a place (Bigne et al., 2001; Chi \& Qu 2008; Yoon \& Uysal 2005).

Since accurate data on the size and location of the population of interest were not available and there were financial and time limitations, non-random convenience sampling technique was applied. Even though non-random samples are described as non-representative, these techniques are quite popular in tourism researches (Chen \& Tsai, 2007; Lee et al., 2005; Martin \& Bosque, 2008) where no "hard facts" concerning the population of interest are available. It is still possible, however, to assess representativeness by comparing the sample with known population characteristics (Gilbert, 2001) and as long as the nature of the sampling is made clear, the reader can judge himself "the extent to which the statistics are appropriate and useful as a guide to the nature of the population" (Sapsford, 1999, p. 91). Therefore, once the required data was collected the sample profile was compared with the characteristics of Linz's visitors in terms of their nationality. According to statistical data published on TourMIS foreign visitors accounted for between 51- 53\% and domestic visitors for $47 \%$ - $49 \%$. It could be concluded that almost a perfect match was assured between the collected data and the official statistics on Linz's visitors' nationality, which contributed significantly to the research representativeness.
Also the sample size is directly linked with the statistical accuracy sought and the number of variables used. Sample size considered as adequate for data analysis requirements should have around 8-10 respondents per item used in an attitudinal questionnaire (Ryan, 1995) and as a general rule for factor analysis (the statistical technique used in the data analysis) the sample should be four or five times as many observations as there are variables to be analysed (Hair et al., 1987) which was the case in the current study.

The representative quality of the sample was assured as a degree of randomness on the selection of respondents by controlling the places ("sampling of places" - different venues, events, attractions) and times of data collection ("sampling of time" - data was collected at different times of the day).

\section{Data analysis and results \\ Data Reduction}

Principal Component Analysis was used for data reduction purposes for both cognitive and affective image dimensions of Linz. The KaiserMayer-Olkin Measure of Sampling Adequacy had values of 0.749 for the cognitive components and 0.743 for the affective components respectively and both domains had Barlett's Test of Sphericity values of .000 , thus proving that the data set is suitable for factor analysis (Pallant, 2007).

The factor analysis for the cognitive components revealed the existence of seven factors with eigenvalues exceeding 1 , which explain $60.19 \%$ of the variance with component 1 contributing 18.95\%, Component $2-10.57 \%$, Component $3-8.07 \%$, Component $4-7.37 \%$, Component 5 - $5.60 \%$, Component $6-5.05 \%$ and Component 7 - $4.67 \%$.

Varimax rotation was used and factor loadings below 0.45 were excluded (four components) following the recommendations of Comrey \& Lee (1992, in Pett et al., 2003).

The computation of Cronbach $\alpha$ indicates that all factors are stable with substantially high internal consistencies ( $\alpha$ for Factor $1=0.786$, $\alpha$ for Factor $2=0.842$, $\alpha$ for Factor $3=0.757, \alpha$ for Factor $4=0.701, \alpha$ for Factor $5=0.677, \alpha$ 
for Factor $7=0.611$ ) except Factor 6 $(\alpha=0.484)$. It was, therefore, accepted that 6 factors were well above the "criterion-in-use" (.60 or higher, Peterson, 1994), and therefore acceptably reliable. In total, 21 cognitive image components managed to be included into the factor analysis as they all showed factor loadings above 0.45 .

The first factor appears to represent "Pastime" in Linz and includes for example the snowy Alps, museums and monuments. The second one reflects Linz's "Blemish" heritage - its' dark Nazi history and heavy industry. The third factor groups Linz's presenters of contemporary culture. Factor IV seems to represent Linz's "Eventness", or in other words, its cultural life by including the two major festivals taking place in Linz and the Austrian composer Bruckner. The penultimate factor is called "Aesthetics" includes Linz's old churches, architecture and old town. Postlingberg (a mountain nearby Linz) was in the final factor called "Relaxation" together with Linz's shopping facilities.

The affective image components of Linz were also factor analysed and a set of five factors was identified with eigenvalues exceeding 1 and explaining $68,55 \%$ of the variance. One of the factors (Tranquillity) showed Chronbach $a$ less than 0.6 and was eliminated from further analysis.

The first factor appears to group the most unappealing and unsympathetic feelings arisen

Table 1. Summary of the PCA for Linz's cognitive image components

\begin{tabular}{|c|c|c|c|c|}
\hline Image Factors and Dimensions & $\begin{array}{l}\text { Factor } \\
\text { Loading }\end{array}$ & $\begin{array}{l}\% \text { of } \\
\text { Variance } \\
\text { Explained }\end{array}$ & $\begin{array}{l}\text { Cumulative \% of } \\
\text { Variance } \\
\text { Explained }\end{array}$ & $\begin{array}{l}\text { Factor } \\
\text { Alpha } \\
\text { Value }\end{array}$ \\
\hline Factor I: Pastime & & 18.860 & 18.955 & 0.786 \\
\hline Alps & 0.829 & & & \\
\hline Snow/Winter & 0.742 & & & \\
\hline Monuments & 0.701 & & & \\
\hline Museums & 0.614 & & & \\
\hline Bicycle Paths & 0.539 & & & \\
\hline Ancient Origin & 0.5000 & & & \\
\hline Factor II: Blemish & & 10.577 & 29.437 & 0.842 \\
\hline Heavy Industry & 0.929 & & & \\
\hline Steel Industry & 0.898 & & & \\
\hline Hitler & 0.757 & & & \\
\hline Factor III: Contemporary Culture & & 8.076 & 37.513 & 0.757 \\
\hline Lentos & 0.852 & & & \\
\hline Modern Art & 0.780 & & & \\
\hline Ars Electronica Center & 0.777 & & & \\
\hline Factor IV: Eventness & & 7.368 & 44.881 & 0.701 \\
\hline International Street Artist Festival & 0.781 & & & \\
\hline Bruckner Festival & 0.780 & & & \\
\hline Bruckner & 0.633 & & & \\
\hline Football & 0.487 & & & \\
\hline Factor V: Aesthetics & & 5.591 & 50.472 & 0.677 \\
\hline Old Churches & 0.814 & & & \\
\hline Old Town & 0.722 & & & \\
\hline Architecture & 0.713 & & & \\
\hline Factor VI: Traditions & & 5.051 & 55.523 & 0.484 \\
\hline Cultural Heritage & 0.680 & & & \\
\hline Austrian Cuisine & 0.537 & & & \\
\hline Factor VII: Relaxation & & 4.670 & 60.193 & 0.611 \\
\hline Postlingberg & 0.807 & & & \\
\hline Shopping & 0.769 & & & \\
\hline
\end{tabular}


by Linz's image - dark, cold and poor. In contrast, the next one groups more encouraging and positive feelings such as modern, interesting and enjoyable and was consequently called "encouraging". Factor III reflects Linz's boredom and unattractive elements and was labelled "discouraging", whereas the final one, the "exquisite" dimensions included for example "admirable" and "beautiful" as parts of Linz's image.

Respondents profile

The whole sample consisted of 400 respondents, 188 of which were Austrians ( $47 \%$ of the total sample) and 212 were Internationals ( $53 \%$ of the total sample) from 22

Table 2. Summary of the PCA for Linz's cognitive image components

\begin{tabular}{|c|c|c|c|c|}
\hline $\begin{array}{l}\text { Image Factors and } \\
\text { Dimensions }\end{array}$ & $\begin{array}{l}\text { Factor } \\
\text { Loading }\end{array}$ & $\begin{array}{l}\% \text { of } \\
\text { Variance } \\
\text { Explained }\end{array}$ & $\begin{array}{l}\text { Cumulative \% } \\
\text { of Variance } \\
\text { Explained }\end{array}$ & $\begin{array}{l}\text { Factor } \\
\text { Alpha } \\
\text { Value }\end{array}$ \\
\hline Factor I: Unsympathetic & & 29.416 & 29.416 & 0.764 \\
\hline Dark & 0.862 & & & \\
\hline Cold & 0.851 & & & \\
\hline Poor & 0.672 & & & \\
\hline Factor II: Encouraging & & 13.281 & 42.698 & 0.733 \\
\hline Modern & 0.812 & & & \\
\hline Interesting & 0.803 & & & \\
\hline Enjoyable & 0.659 & & & \\
\hline Factor III: Discouraging & & 9.757 & 52.455 & 0.642 \\
\hline Unpleasant & 0.831 & & & \\
\hline Boring & 0.794 & & & \\
\hline Factor IV: Exquisite & & 8.736 & 61.191 & 0.736 \\
\hline Admirable & 0.876 & & & \\
\hline Beautiful & 0.801 & & & \\
\hline Factor V: Tranquillity & & 7.363 & 68.554 & 0.597 \\
\hline Calm & 0.843 & & & \\
\hline Neat & 0.794 & & & \\
\hline
\end{tabular}

Table 3. Respondents' demographic profile

\begin{tabular}{llll} 
& & Frequency & Percent \\
\cline { 3 - 4 } Nationality & Austrians & 188 & 47 \\
& Internationals & 212 & 53 \\
Gender & Female & 215 & 53.8 \\
& Male & 185 & 46.3 \\
& $18-25$ & 34 & 8.5 \\
& $26-30$ & 42 & 10.5 \\
& $31-35$ & 41 & 10.3 \\
& $36-40$ & 48 & 12 \\
Professional & $41-45$ & 46 & 11.5 \\
Status & $46-50$ & 73 & 18.3 \\
& $51-55$ & 45 & 11.3 \\
& $56+$ & 71 & 17.8 \\
& Full-time employed & 230 & 57.5 \\
Education & Part-time employed & 65 & 16.3 \\
& Students & 29 & 7.3 \\
& Retired & 62 & 15.5 \\
& Other & 14 & 3.5 \\
& Primary & 29 & 7.3 \\
& Secondary & 142 & 35.5 \\
& University & 229 & 57.3 \\
\hline
\end{tabular}


different countries. In terms of gender $54 \%$ of the respondents were female and $46 \%$ were male. The age distribution was almost equal across the different age intervals, however, two of the groups $46-50$ and above 56 represented in total almost $40 \%$ of the whole sample. The majority of the respondents were in full-time employment (58 \%) and with a university degree $(57 \%)$.

Relationship between Linz's destination image and respondents' level of loyalty

The variables "recommendation" and "revisit" were dummy variables with yes or no as possible answers. Destination loyalty index was calculated as a composite of intention to return to Linz (yes/no) and intention to recommend it (yes/no) following Baloglu's (2001) way of calculating a familiarity index. The answers were grouped into two subcategories for each of the variables - a score of 0 was used to code the "no" answers and a score of 1 was given to the "yes answers". By cross-tabulating the recommendation and revisit dimensions the following table was produced:

The revisit and recommendation dimensions scores were added for each individual, which resulted in a destination loyalty index ranging from 0 to 2. The respondents with a score of 0 were brought into a "low loyalty" group, those with a score of 1 into a "medium loyalty" group and finally "high loyalty" group included respondents who received a score of 2 .

To assess the destination loyalty group differences across the image components of Linz a Multivariate Analysis of Variance was utilized. The multivariate significance tests (Pillai's Trace, Hotellings's Trace, Wilks' Lambda and Roy's Largest Root) produced by MANOVA were all significant at 0.01 level and thus showed that there were significant differences between the three different groups of destination loyalty. Consequently, a post-hoc Scheffe test was conducted on univariate statistics (ANOVAs) in order to identify which image dimensions differentiate the three groups. The table below shows the mean scores of Linz's image dimensions for each group.

Significant differences between the groups were found for four (out of six) cognitive image dimensions and for all affective image domains. "Pastime" was found to significantly differentiate two of the destination loyalty groups $(p=0.011$, less than 0,05$)$ - the higher the loyalty index, the higher the level of agreement with "pastime" as image dimension of Linz. The next cognitive image domain "Blemish" $(p=0.030$, less than 0.05$)$ also demonstrated that there are significant differences between the "low" and "high" destination loyalty groups the higher the loyalty index the higher the level of disagreement. "Contemporary Culture" was found to also significantly $(p=0.021$, less than 0.05 ) differentiate all the groups, where the "low destination loyalty" group was giving the lowest level of agreement and the rest two groups were almost equal at 1.52 and 1.54 on average.

In relation to the affective image components, there is a clear, statistically significant positive trend - the higher the composite destination loyalty index, the higher the level of agreement with Linz's positive affective image components such as "Encouraging" and "Exquisite". Consequently, the lower the destination loyalty, the higher the level of agreement with Linz's negative image characteristics (unsympathetic, discouraging). It could be concluded that Linz's image perceived by the "high destination loyalty" group seems to be significantly more positive than the image of Linz held by the respondents allocated to the "low and moderate destination loyalty" groups.

Table 4. Cross-table between tourist attitudinal loyalty and behavioural loyalty

\begin{tabular}{lll}
\hline $\begin{array}{l}\text { Revisit } \\
\text { Dimension }\end{array}$ & \multicolumn{2}{l}{ Recommendation dimension } \\
\hline No $(0)$ & No $(0)$ & Yes $(1)$ \\
& $29(0+0)$ & $149(0+1)$ \\
Yes (1) & $6(0+1)$ & $216(1+1)$ \\
\hline
\end{tabular}


Tourism destination image as an antecedent of destination loyalty: The case of Linz, Austria.

Table 5. Results of univariate analysis of variance with post-hoc Scheffe test on respondents' loyalty level and its relationship with Linz's image

\begin{tabular}{llllll}
\hline $\begin{array}{l}\text { Image } \\
\text { Dimensions }\end{array}$ & $\begin{array}{l}\text { Low } \\
\text { destination } \\
\text { loyalty } \\
\mathbf{n = 2 9}\end{array}$ & $\begin{array}{l}\text { Moderate } \\
\text { destination } \\
\text { loyalty } \\
\mathbf{n = 1 5 5}\end{array}$ & $\begin{array}{l}\text { High } \\
\text { destination } \\
\text { loyalty } \\
\mathbf{n = 2 1 6}\end{array}$ & F-value & Significance \\
\hline Pastime & $3.511 \mathrm{a}$ & 3.206 & $3.049 \mathrm{a}$ & 4.531 & 0.011 \\
Blemish & $2.678 \mathrm{a}$ & 3.084 & $3.199 \mathrm{a}$ & 3.540 & 0.030 \\
Contemporary & $1.897 \mathrm{a}, \mathrm{b}$ & $1.523 \mathrm{a}$ & $1.543 \mathrm{~b}$ & 3.913 & 0.021 \\
culture & & & & & \\
Eventness & 3.509 & 3.434 & 3.324 & 0.592 & 0.554 \\
Aesthetics & 1.287 & 1.211 & 1.199 & 0.756 & 0.470 \\
Relaxation & $1.724 \mathrm{a}$ & 1.503 & $1.449 \mathrm{a}$ & 4.179 & 0.016 \\
Unsympathetic & $4.460 \mathrm{a}$ & 4.652 & $4.727 \mathrm{a}$ & 3.724 & 0.025 \\
Encouraging & $2.609 \mathrm{a}, \mathrm{b}$ & $1.961 \mathrm{a}$ & $1.890 \mathrm{~b}$ & 27.552 & 0.000 \\
Discouraging & $3.759 \mathrm{a}, \mathrm{b}$ & $4.816 \mathrm{a}$ & $4.838 \mathrm{~b}$ & 63.036 & 0.000 \\
Exquisite & $2.845 \mathrm{a}, \mathrm{b}$ & $1.913 \mathrm{a}$ & $1.808 \mathrm{~b}$ & 31.325 & 0.000 \\
\hline
\end{tabular}

${ }^{a}$ Mean scores with different letters are significantly different at 0.05 probability level from each other.

\section{Discussion and Conclusion}

A variety of travellers' decision making models have already recognized the importance of destination image in choosing the right place to visit (Gartner, 1989; Lee et al., 2005; Molina \& Esteban, 2006; Ramkissoon et al. 2011; Yüksel \& Akgül, 2007). The importance of tourist loyalty in terms of intention to revisit and recommend is vital for any destination (Korte, 1995; Lee, 2003) since loyal holiday-makers are generally perceived as stable profit providers (Eagles, 2001; Korte, 1995; Lee, 2003) and destinations' ambassadors. Yet, very little was found in the literature on the link between these two crucial concepts and this area of research appears as rather neglected in the existing tourism literature. Despite the significant number of researches on destination image and tourist loyalty, the multi-dimensional nature of their constructs makes establishing a clear link between them a difficult task (Zhang et al., 2014). There are only three studies (Nadeau et al. 2008; Hu, 2010; Shen, 2012) that attempt to clarify the link between cognitive and affective components and composite loyalty, which is the combination of attitudinal and behavioural loyalty. This study, therefore, set out with the aim of exploring the relationship between destination image constructed as consisting of cognitive and affective elements and composite loyalty which embraces attitudinal and behavioural loyalty. Knowing how to use the image of a place to convert first-time visitors into loyal holidaymakers and destination ambassadors and how to strengthen attitudinal and behavioural loyalty is crucial for destination marketers.

The current study implies that people with a positive image of Linz are more likely to have a higher composite loyalty index which could lead to revisits or recommendations. This finding complements previous studies that have also suggested a positive relationship between destination image and loyalty (Alcaniz et al., 2009; Bigné, et al., 2001; Bosque \& Martín, 2008; Castro et al., 2007; Chen \& Tsai, 2007; Chi \& Qu, 2008; Court \& Lupton, 1997; Faullant et al., 2008; Lee et al., 2008; Mahasuweerachai \& Qu, 2011; Sun et al., 2013; Um et al., 2006; Yoon \& Uysal, 2005). For example, respondents with high composite loyalty levels (e.g. willing to recommend and to revisit Linz) had more positive attitude towards Linz's "Contemporary Culture" and "Pastime" and thought of Linz as a an exquisite and enjoyable place to visit. Also, the results point at the importance of "Contemporary Culture" to act as a magnet for re-visiting and recommending Linz as it had significant influence over the respondents' loyalty towards Linz. This finding suggests that Linz's authorities should endeavour to retain these features of its image in order to transform first-time visitors into repeat visitors and destination ambassadors. This could be achieved by improving the cultural life in the town by focusing on contemporary art exhibitions and performances and by developing and offering existing activities in the town and its surroundings for visitors to enjoy. 
The results also provide indications that there are significant differences between "low" and "high" composite destination loyalty groups in terms of the way they perceive Linz's "Blemish" domain - the higher the loyalty index, the higher the level of disagreement with "Blemish", which leads to the proposition that Linz's dark past is not a factor that would mar its visitors intention to recommend it or to revisit it. One of the issues that emerged from these findings is that destinations struggling to refine their image should encourage destination loyalty among their visitors as visitors' with high or even moderate composite loyalty tend to "forgive" image imperfections and still revisit and recommend the place.

However, with regards to the role cognitive and affective image components play in the process of developing destination loyalty, some discrepancies among the very limited number of studies on this issue became noticeable. From the overall data analysis it appears that both cognitive and affective destination image characteristics are almost equally influential on visitors' composite loyalty (see Table 9 below). For instance, Alcaniz et al., (2009) and Chen \& Tsai (2007) have pointed out that the cognitive destination image has a direct effect on tourists' behavioural intentions, which was confirmed by the current study as three out of six cognitive image elements were found to be in a significant relationship with level of loyalty. In contrast, White (2003), and Yu and Dean (2001), however, argued that the affective image components are better predictors than the cognitive ones, and thus evaluation of affective qualities of destinations might be of a higher importance than evaluation of the objective, perceivable properties of places (Kim \& Richardson, 2003), which was also supported in this study by all affective image components and the respondents' loyalty towards Linz. It could, therefore, be suggested that when it comes to increasing visitors' composite loyalty, destination marketers should not neglect visitors' feelings; attachment and attitude towards the destination since destination's affective image appear to be slightly more influential on tourists' behavioural intentions than destination's cognitive image. Therefore, the suggestion that both cognitive and affective image components have an important impact on tourists' composite loyalty has its merits.

This research has contributed to the body of knowledge on destination image and tourist composite loyalty in several ways. Firstly, it discussed and empirically proved the positive relationship between destination image and tourist composite loyalty by integrating their multi-layered dimensions. Secondly, the composite tourist loyalty was measured by calculating a loyalty index consisting of two dimensions - revisit intentions and recommendation intentions. The novelty of this index allows for a precise distinction between different nuances of composite tourist loyalty "low", "moderate" and "high" to be made, which enabled in-depth statistical tests to be conducted and to establish the impact of destination image on these different levels of loyalty. Thirdly, the conceptualizing of destination image and the findings related to the impact of both cognitive and affective image components on composite loyalty also deserve explicit attention as there are still not sufficient studies on destination image that acknowledge its cognitive-affective nature. Fourthly, the results provide some justifiable evidence that affective image components exert stronger influence on the composite tourist loyalty compared to the cognitive ones.

The findings of this study have several practical implications too. Knowing and appreciating the impact of positive image on visitors' composite loyalty would enable more focused destination image development strategies and marketing campaigns. A place with a positive image is more likely to be revisited and recommended to fellow travellers. The type of feelings and emotions a place evoke in its visitors also deserve managerial attention and inclusion into promotional activities as it was proved that the impact they have on visitors' loyalty is greater than the impact of knowledge, beliefs and expectations about it.

Despite the effort to follow strict scientific criteria throughout this research, it clearly has certain conceptual and methodological limitations. While this research aimed at exploring the relationship between visitors' composite loyalty and destination image, the 
destination in question was a small European town and other types of destinations (e.g. islands, countries, rural destinations) were not included in the research and the emerged findings must be interpreted with caution. Results generalization could, therefore, be seen as another research limitation since the research of a destination allows the results to be generalized only for the research sample and the destination in question. It also needs to be mentioned that the sample was perceived as mainly homogenous in terms of distance (country of origin) from Linz as the majority of respondents came from other European countries and only a small fraction of the sample represented the rest of the world. Also, the study attempted to mainly explore the link between destination image and composite loyalty and did not take into consideration other variables such as satisfaction or sociodemographic characteristics and their potential impact over this relationship. The above mentioned limitations do not invalidate the key findings of the research, but only slightly compromise their external validity.

A profound understanding of the link between destination image and visitors loyalty is of a significant importance for destinations striving to improve and strengthen their positioning in the holiday market. This work addressed relevant, but still under-researched issues that play an important role in the process of promoting and managing destinations and presently there are still some questions that remain unanswered. It will be, therefore, worthwhile to replicate this research at a different destination and in a different context to prove and validate the established link between destination image and tourists composite loyalty. Also a second order factor analysis and a discriminant validity analysis could be applied to prove the reliability of the suggested relationship. A further study with more focus on destination image, composite loyalty and satisfaction could also be suggested.

\section{References}

Alcaniz, E., Sanchez, I. \& Blas, S. (2009). The functional-psychological continuum in the cognitive image of a destination: a confirmatory analysis, Tourism Management, 30, 715-723.
Alegre, J., \& Cladera, M. (2006). Repeat visitation in mature sun and sand holiday destinations. Journal of Travel Research, 44, 288-297.

Alexandris, K., Kouthouris, C., \& Meligdis, A. (2006). Increasing customers' loyalty in a skiing resort. International Contemporary Hospitality Management, 18(5), 414- 425.

Assaker, G., Vinzi, E., \& O'Connor, P. (2011) Examining the effect of novelty seeking, satisfaction, and destination image on tourists' return pattern: A two factor, nonlinear latent growth model. Tourism Management, 32, 890- 900.

Backman, S., \& Crompton, J. (1991). The usefulness of selected variables for predicting, activity loyalty. Leisure Science, 13(3), 205-220.

Bagozzi, P. (1992). The self-regulation of attitudes, intentions and behavior. Social Psychology Quarterly, 55, 178-204.

Bagozzi P., \& Burnkrant R. (1985). Attitude organization and the attitude-behavior relation: A reply to Dilon and Kumar. Journal of Personality and Social Psychology, 49, 47-57.

Baldinger, A., \& Rubionson, J. (1996). Brand loyalty: the link between attitude and behavior. Journal of Advertising Research, 36(6), 22-34.

Baloglu, S. (2001). Image variations of Turkey by familiarity index: Informational and experiential dimensions. Tourism Management, 22 (2), 127-133.

Baloglu, S., \& Brinberg, D. (1997). Affective Images of Tourism Destinations. Journal of Travel Research, 35 (4), 11-15.

Baloglu, S., \& Love, C. (2005). Association meeting planners' perceptions and intentions for five major US convention cities: the structured and unstructured images. Tourism Management 26 (5), 743-752.

Baloglu, S., \& McCleary, K. (1999). A Model of Destination Image Formation. Annals of Tourism Research, 26 (4), 868-897.

Beerli, A., \& Martin, J. (2004). Tourists' characteristic and the perceived image of tourist destinations: A quantitative analysis A case study of Lanzarote, Spain, Tourism Management, 25 (5), 623-636.

Bigne, J., Sanchez, M., \& Sanchez, J. (2001). Tourism image, evaluation variables and 
after purchase behaviour: Interrelationships. Tourism Management, 22 (6), 607-616.

Bình, N. (2015) A confirmation of the fourcomponent structure of destination image, and their relationships with tourists' loyalty. European Journal of Tourism Research 11, 147-153

Bodet, G. (2008). Customer satisfaction and loyalty in service: two concepts, four constructs, several relationships. Journal of Retailing and Consumer Services, 15(3), 156-162.

Bowen, D. (2001) Antecedents of consumer satisfaction and dissatisfaction (CS/D) on long haul inclusive tours: To reality check on theoretical considerations, Tourism Management, 22(1), 305-314.

Campo-Martínez, S., Garau-Vadell, B., \& Martínez-Ruiz, P. (2010). Factors influencing repeat visits to a destination: the influence of group composition. Tourism Management, 31(6), 862-870.

Carroll, B., \& Ahuvia, A. (2006). Some antecedents and outcomes of brand love. Market Letter, 17, 70-89.

Castro, C., Armario, E., \& Ruiz, D. (2007). The influence of market heterogeneity on the relationship between a destination's image and tourists' future behavior. Tourism Management, 28(1), 175-187.

Chang, E. \& Tseng, Y. (2013). Research note: E-store image, perceived value and perceived risk. Journal of Business Research, 66(7), 864-870.

Chang, L., Stylos, N., Yeh, S. \& Tung, Y. (2015). How do Motivation, Pre-Visit Information Search and Destination Image affect Post-Visit Behavioural Intention? The case of an island destination. European Journal of Tourism Research, 9, 8-23.

Chen, J., \& Gursoy, D. (2001). An investigation of tourists' destination loyalty and preferences. International Journal of Contemporary hospitality Management, 13, 79-86.

Chen, C. \& Phou, S. (2013). A closer look at destination: Image, personality, relationship and loyalty. Tourism Management, 36, 269278.

Chen, C.F \& Tsai, D. (2007). How destination image and evaluative factors affect behavioural intentions? Tourism Management, 28 (7), 1115-1122.
Chi, C. \& Qu, H. (2008). Examining the structural relationships of destination image, tourist satisfaction and destination loyalty: An integrated approach. Tourism Management, 29(4), 624-636.

Comrey, L. A. \& Lee, H.,B. (1992). A first course of factor analysis, Hillsdale, $\mathrm{NJ}$ : Lawrence Elbraum.

Correia Loureiro, S. M., \& Miranda Gonza'lez, F. J. (2008). The importance of quality, satisfaction, trust, and image in relation to rural tourist loyalty. Journal of Travel \& Tourism Marketing, 25(2), 117-136.

Court, B., \& Lupton, R. A. (1997). Customer portfolio development, Modeling destination adopters, inactives, and rejecters. Journal of Travel Research, 36 (1), 85-89.

Crompton, J. (1979). An Assessment of the Image of Mexico as a Vacation Destination and the Influence of Geographical Location upon that Image. Journal of Travel Research, 17 (4), 18-23.

Crouch, G. (2011). Destination Competitiveness: An Analysis of Determinant Attributes, Journal of Travel Research, 50 (1), 27-45.

Dick, A. S., \& Basu, K. (1994). Customer loyalty: toward an integrated conceptual framework. Journal of the Academy of Marketing Science, 22(2), 99-113.

Dumont, E., Asensio, M., \& Mortari, M. (2010). Image, Construction and Representation in Tourism Promotion and Heritage Management. In: Burns, P., Palmer, C. and Lester, J. A. (Eds.) Tourism and visual culture, Volume 1: Theories and concepts. 124-138.

Echtner, M., \& Ritchie, J. (1991). The meaning and measurement of destination image, Journal of Travel Studies, 2 (2), 2-12.

Echtner, M., \& Ritchie, J. (1993). The Measurement of Destination Image: An Empirical Assessment. Journal of Travel Research, 31 (4), 3-13.

Fang, F. (2008). A study of the relationship between destination image and behavioral intention based on tourists' perception: A case study of West Lake Scenic Area. Unpublished thesis. Hangzhou, China: Zhe Jiang University.

Faullant, R., Matzler, K. \& Füller, J. (2008). The impact of satisfaction and image on loyalty: 
the case of Alpine ski resorts, Managing Service Quality, 18 (2), 163 - 178.

Field, A. (2005) Discovering Statistics Using SPSS ( $2^{\text {nd }}$ ed. $)$ London, SAGE.

Floh, A., Zauner, A., Koller, M., \& Rusch, T. (2013). Customer segmentation using unobserved heterogeneity in the perceivedvalue-loyalty-intentions link. Journal of Business Research. 67, (5), 974-982

Forgas-Coll, S., Palau-Saumell, R., SanchezGarcia, J., \& Callarisa-Fiol, L. J. (2012). Urban destination loyalty drivers and crossnational moderator effects: The case of Barcelona. Tourism Management, 33, 1309-1320.

Fournier, S. (1994). A consumer-brand relationship framework for strategy brand management. Unpublished thesis. University of Florida.

Fridgen, J. (1987). Use of cognitive maps to determine perceived tourism regions. Leisure Sciences, 9 (1), 101-117.

Gallarza M., Gil, I., \& Calderon, H. (2002). Destination Image: Towards a Conceptual Framework. Annals of Tourism Research, 29 (1), 56-78.

Gartner, W. (1989). Tourism Image: Attribute Measurement of State Tourism Products using Multidimensional Scaling Techniques. Journal of Travel Research, 28 (2), 16-20.

Gartner, W. (1993). Image Formation Process. Journal of Travel and Tourism Marketing, 2 (2/3), 191-215.

Gilbert, N. G. (2001) Researching social life. $2^{\text {nd }}$ ed., Sage.

Hair, J. F., Anderson, R. \& Tatham, R. (1987) Multivariate Data Analysis with Readings Macmillan, New York.

Hanyu, K. (1993). The Affective Meaning of Tokyo: Verbal and Nonverbal Approaches. Journal of Environmental Psychology, 13, 161-72.

Hawkins, D., Best, R., \& Coney, K. (1989). Consumer behavior: Implication for marketing strategy (4th edn.). Homewood, IL: BPI/Irwin.

Ho, R. (2006). Handbook of Univariate and Mutlvariate Data Analysis and Interpretation with SPSS, Taylor and Francis Group, Boca Raton.

Horng, J., Liu, S., Chiu, H., \& Tsai, C. (2011). The role of international tourist perceptions of brand equity and travel intention in culinary tourism. The Service Industries Journal, 32(16), 1-15.

Hosany, S., Ekinci, Y., \& Uysal, M. (2006). Destination image and destination personality: an application of branding theories to tourism places. Journal of Business Research, 59, 638-642.

Hou, J., Lin, C., \& Morais, D. (2005). Antecedents of attachment to a cultural tourism destination: the case of Hakka and non-Hakka Taiwanese visitors to Pei-Pu, Taiwan. Journal of Travel Research, 44, 221-233.

$\mathrm{Hu}$, F. (2010). The relationship between visitors' perceived image and loyalty in YueLu Mountain Scenic Area. Unpublished thesis. Changsha, China: HuNan Normal University.

Hunt, J. D. (1975). Image as a factor in tourism development, Journal of Travel Research, 13, 1-7.

Hyun, M., \& O'Keefe, R. (2012). Virtual destination image: testing a telepresence model. Journal of Business Research, (1), 29-35.

Iwaskaki, Y., \& Havitz, M. (1998). A path analytic model of the relationships between involvement, psychological commitment, and loyalty. Journal of leisure research, 30(2), 256-280.

Jacoby, J., \& Chestnut, R. (1978). Brand loyalty: Measurement and management. New York: John Wiley and Sons.

Jang, S. \& Feng, R. (2007). Temporal destination revisit intention: The effects of novelty seeking and satisfaction. Tourism Management. 28, 580-590.

Jenkins, O. (1999). Understanding and Measuring Tourist Destination Image. International Journal of Tourism Research, 1, 1-15.

Jennings, G. (2010). Tourism Research. $2^{\text {nd }}$ ed. John Wiley \& Sons.

lordanova, E. (2015). Unravelling the complexity of destination image formation: A conceptual framework. European Journal of Tourism Research, 11, pp. 35-56.

lordanova - Krasteva, E., Wickens, E., and Bakir, A. (2010). The Ambiguous Image of Linz. PASOS, 8 (3), pp. 67-77.

Kaplanidou, K., \& Gibson, H. (2010). Predicting behavioral intentions of active event sport tourists: the case of a small-scale recurring 
sports event. Journal of Sport and Tourism, 15(2), 163-179.

Kastenholz, E. (2004). Assessment and role of destination-self-congruity. Annals of Tourism Research, 31(3), 719-723.

Kim, D., \& Perdue, R. (2011). The Influence of Image on Destination Attractiveness. Journal of Travel and Tourism Marketing. 4 (28), 225-239.

Kim, H., \& Richardson, S. (2003). Motion Picture Impacts on Destination images. Annals of Tourism Research, 30 (1), 216-237.

Kim, S., \& Morrison, A. (2005). Changes of images of South Korea among foreign tourists after the 2002 FIFA World Cup. Tourism Management, 26(2), 233-247.

Kneesel, E., Baloglu, S. \& Millar, M. (2010). Gaming Destination Images: Implications for Branding, Journal of Travel Research, 49 (1), 68-78.

Ko, W. \& Park, H. (2000). Five Aspects of Tourism Image: A Review. International Journal of Tourism Science, 1 (1), 79-92.

Korte, C. (1995). Kundenzufriedenheit, Planung und Analyse, 6, 36-9.

Kumar, R. (2005). Research Methodology: A Step by Step Guide for Beginners, $2^{\text {nd }}$ ed., SAGE Publications.

Lee, J. (2014). Visitors' emotional responses to the festival environment. Journal of Travel and Tourism Marketing, 31(1), 114-131

Lee, C., Yoon, Y. \& Lee, S. (2007). Investigating the relationships among perceived value, satisfaction, and recommendations: the case of Korean DMZ. Tourism Management 28(1), 204-214.

Lee, T. (2009). A Structural Model to Examine How Destination Image, Attitude, and Motivation Affect the Future Behavior of Tourists, Leisure Sciences: An Interdisciplinary Journal, 31(3), 215-236.

Lee, C., Backman, K., \& Backman, S. (1997). Understanding antecedents of repeat visitation and tourists' loyalty to a resort destination. Proceedings of the 1997 Travel and Tourism Research Association Annual Conference, TTRA, Boulder, CO.

Lee, J., \& Back, B. (2008). Attendee-based brand equity. Tourism Management, 29, 331-344.

Lee, J., Graefe, A., \& Burns, R. (2007). Examining the antecedents of destination loyalty in a forest setting. Leisure Science, 29, 463-481.

Lee, K., Lee, K., \& Lee, K. (2005). Korea's destination image formed by the 2002 World Cup. Annals of Tourism Research, 32(4), 839-858.

Leisen, B. (2001). Image segmentation: the case of a tourism destination. Journal of Services Marketing, 15(1), 49-66.

Lewonig, J. (2007). Linz expects a New Image. Retrieved from: http://www.culturelive.It/en/vilnius2009/news /news1-newimage/ (Accessed on 21.05.2009).

Li, X., \& Petrick, J. F. (2008). Examining the antecedents of brand loyalty from an investment model perspective. Journal of Travel Research, 47, 25-34.

Li, M., Cai, L., Lehto, X., \& Huang, J. (2010). A missing link in understanding revisit intention: the role of motivation and image. Journal of Travel and Tourism Marketing, 27(4), 335-348.

Lin, C., Morais, D., Kerstetter, D., \& Hou, S. (2007). Examining the role of cognitive and affective image in predicting choice across natural, developed, and theme-park destinations. Journal of Travel Research, 46(2), 183-194.

Lincoln, Y. S. (1990). The making of a constructivist: a remembrance of transformations past. In: Guba E, G (Ed.) The paradigm dialog. Newbury Park, CA: Sage. pp. 67-87.

Linz European Capital of Culture (2009). Mission Statement. Retrieved from: http://www.linz09.at/en/missionstatement.html (Accessed on 20.02. 2009).

Lobato, L., Solis-Radilla, M., Moliner-Tena, A., \& Sánchez- García, J. (2006). Tourism destination image, satisfaction and loyalty: a study in Ixtapa-Zihuatanejo, Mexico. Tourism Geographies, 8(4), 343-358.

Mahasuweerachai, P., \& Qu, H. (2011). The impact of destination image on value, satisfaction, and loyalty: Moderating effects of tourist characteristics and involvement. In 16th Annual graduate education and graduate student research conference in hospitality and tourism. TX, USA: Houston.

Martin, H., \& Bosque, R. (2008). Exploring the cognitive-affective nature of destination image and the role of psychological factors 
in its formation. Tourism Management 29, 263-277.

Maykut, P. \& Morehouse, R. (1994). Beginning Qualitative Research; A Philosophic and Practical Guide, The Falmer Press, London; Washington, D.C.

Mazanec, J. (2000). Introduction: Reports from the second symposium on the consumer psychology of tourism, hospitality and leisure (CPTHL). Tourism Analysis, 5, 64-68.

Mazanec, J., \& Schweiger, G. (1981). Improved Marketing Efficiency through Multiproduct Brand Names? An Empirical Investigation of Image Transfer. European Research, 9, 3244.

Mazursky, D., \& Jacoby, J. (1986). Exploring the Development of Store Images. Journal of Retailing, 62 (2),145-165.

Mechinda, P., Serirat, S., \& Gulid, N. (2009). An examination of tourists' attitudinal and behavioral loyalty: Comparison between domestic and international tourists. Journal of Vacation Marketing, 15(2), 129-148.

Milman, A., \& Pizam, A. (1995). The Role of Awareness and Familiarity with a Destination: The Central Florida Case. Journal of Travel Research, 33 (3), 21-27.

Mittal, B., \& Lasar, M. (1998). Why do customers switch? The dynamics of satisfaction versus loyalty. The Journal of Services Marketing, 12, 177-194.

Molina, A. \& Esteban, A. (2006). Tourism Brochures: Image and Usefulness. Annals of Tourism Research, 33 (4), 1036-1056.

Moore, S.A., Rodger, K., \& Taplin, R. (2013). Moving beyond visitor satisfaction to loyalty in nature-based tourism: A review and research agenda. Current Issues in Tourism, 1-17.

Rodger, K., Taplin, R. \& Moore, S. (2015). Using a randomised experiment to test the causal effect of service quality on visitor satisfaction and loyalty in a remote national park. Tourism Management, 50, 172-183

Nadeau, J., Heslop, L., O'Reilly, N., \& Luk, P. (2008). Destination in a country image context. Annals of Tourism Research, 35(1), $84-106$.

Oliver, R. L. (1997). Satisfaction: a behavioral perspective on the consumer. New York: Irwin/McGraw-Hill.
Oliver, L. (1999). Whence consumer loyalty? Journal of Marketing, 63(Special issue), 3344.

Pallant, J. (2007). SPSS Survival Manual, A Step by Step Guide to Data Analysis using SPSS for Windows, $3^{\text {rd }}$ ed. Maidenhead Open University Press.

Pandža Bajs, I. (2013). Tourist Perceived Value, Relationship to Satisfaction, and Behavioural Intentions: The Example of the Croatian Tourist Destination Dubrovnik. Journal of Travel Research, 1-13

Pedersen, P., \& Nysveen, H. (2001). Shopbot banking: an exploratory study of customer loyalty effects. The International Journal of Bank Marketing, 19(4/5), 146-155.

Peterson, K. (1994). The heritage resource as seen by the tourist: The heritage connection. In: Van Harssel, J. (ed.) Tourism: an Exploration, 3rd ed. Englewood Cliffs: Prentice Hall.

Pett, M.A., Lackey, N. R., \& Sullivan, J.J. (2003). Making Sense of Factor Analysis: The Use of Factor Analysis for Instrument Development in Health Care Research, London, Sage.

Pike, S. (2006). Destination decision sets: a longitudinal comparison of stated destination preferences and actual travel. Journal of Vacation Marketing, 12(4), 319328.

Pike, S., \& Ryan, C. (2004). Destination Positioning Analysis through a Comparison of Cognitive, Affective, and Conative Perceptions. Journal of Travel Research, 42, 333-342.

Pike,S., \& Mason, R. (2011). Destination competitiveness through the lens of brand positioning: the case of Australia's Sunshine Coast. Current Issues in Tourism. 14 (2), 169-182.

Pocock, D., \& Hudson, R. (1978). Images of the Urban Environment. Macmillan Press: London.

Qu, H., Kim, H., \& Im, H. (2011). A model of destination branding: Integrating the concepts of the branding and destination image, Tourism Management, 32, 465-476.

Ramkissoon, H., Uysalb, M. \& Brownc, K. (2011). Relationship between destination image and behavioral intentions of tourists to consume cultural attractions. Journal of 
Hospitality Marketing and Management. 20 (5), 575-595.

Ramseook-Munhurrun, P., Seebaluck, V. \& Naidoo, P. (2015). Examining the structural relationships of destination image, perceived value, tourist satisfaction and loyalty: case of Mauritius. Social and Behavioral Sciences, 175, 252 - 259.

Reilly, M. D. (1990). Free Elicitation of Descriptive Adjectives for Tourism Image Assessment. Journal of Travel Research, 28 (4),69-76.

Rodrigues, A. I., Correia, A. \& Kozak, M. (2011). A Multidisciplinary Approach on Destination Image Construct. Tourismos: An International Multidisciplinary Journal of Tourism, 6 (3), 93-110.

Russell, J. A. (1980). A Circumplex Model of Affect. Journal of Personality and Social Psychology 39, 1161-1178.

Ryan, C. (1995). Researching Tourist Satisfaction: Issues, Concepts, Problems. London: Routledge.

Sapsford, R. (1999). Survey Research, Thousand Oaks, CA: Sage Publications.

Selin, R., Howard, U., \& Cable, T. (1988). An analysis of consumer loyalty to municipal recreation programs. Leisure Science, 10, 210-223.

Shen, P. (2012). The effects of social responsibility of tourism enterprises on destination image and tourist loyalty. Tourism Tribune, 27(2), 72-79.

Simpson, M., \& Siquaw, J. (2008). Destination word-of-mouth: the role of traveller type, residents, and identity salience. Journal of Travel Research, 47 (2), 167-182.

Song, H., You, G.., Reisinger, Y., Lee, C., \& Lee, S. (2014). Behavioral intention of visitors to an oriental medicine festival: an extended model of goal directed behavior. Tourism Management, 42, 101-113

Sonmez, S. \& Sirakaya, E. (2002). A Distorted Destination Image? The Case of Turkey, Journal of Travel Research 41,185-196.

Stepchenkova, S. \& Eales, J. (2011). Destination Image as Quantified Media Messages: The Effect of News on Tourism Demand. Journal of Travel Research. 50(2), 198- 212.

Suhartanto, D., Ruhadi and N. Triyuni (2016). Tourist loyalty toward shopping destination: the role of shopping satisfaction and destination image. European Journal of Tourism Research 13, 84-102

Sun, X., Chi, C., \& Xu, H. (2013). Developing Destination Loyalty: The case of Hainan Island. Annals of Tourism Research, 43, 547-577.

Tasci, A., Gartner, W. \& Cavusgil, S. (2007). Conceptualization and operationalization of destination image. Journal of Hospitality and Tourism Research, 31, 194-223.

Tian-Cole, S., \& Crompton, J. L. (2003). A conceptualization of the relationships between service quality and visitor satisfaction, and their links to destination selection. Leisure Studies, 22(1), 65-80.

Um, S., Chon, K., \& Ro, Y. (2006). Antecedents of revisit intention. Annals of Tourism Research, 33(4), 1141-1158.

Vassiliadis, C. A., Priporas, C. V., \& Andronikidis, A. (2013). An analysis of visitor behaviour using time blocks: A study of ski destinations in Greece. Tourism Management, 34, 61-70.

Walmsley, D. J., \& Young, M. (1998). Evaluative Images and Tourism: The Use of Personal Constructs to Describe the Structure of Destination Images. Journal of Travel Research, 36 (3), 65-69

Wang, C., \& Hsu, M. (2010). The Relationships of Destination Image, Satisfaction, and Behavioral Intentions: An Integrated Model. Journal of Travel and Tourism Marketing, 27 (8), 829-843.

Weaver, D. B., \& Lawton, L. J. (2011). Visitor loyalty at a private South Carolina protected area. Journal of Travel Research, 1-12.

White, C.J. (2003). Emotions, gender and destination visitation intentions. Paper presented at the 12th International Tourism and Leisure Symposium, Barcelona.

Wong, J., Wu, H., \& Cheng, C. (2014). An empirical analysis of synthesizing the effects of festival quality, emotion, festival image and festival satisfaction on festival loyalty: a case study of Macau food festival. International Journal of Tourism Research, 17 (6), 521-536.

Woodside, A. G., \& Dubelaar, C. (2002). A general theory of touism consumption systems: A conceptual framework and an empirical exploration. Journal of Travel Research, 41, 120-132. 
Yang J., Yuan, B., \& Hu, P. (2009). Tourism destination image and Visit Intention. Examining the Role of Familiarity. Journal of China Tourism Research, 5, 174-187.

Yoon, Y., \& Uysal, M. S. (2005). An examination of the effects of motivation and satisfaction on destination loyalty: a structural model. Tourism Management, 26(1), 45-56.

Yu, Y. T., \& Dean, A. (2001). The contribution of emotional satisfaction to consumer loyalty. International Journal of Service Industry Management, 12(3), 234-251.

Yuksel, A., Yuksel, F., \& Bilim, Y. (2010). Destination attachment: effects on customer satisfaction and cognitive, affective and conative loyalty. Tourism Management, 31, 274-284.
Yüksel, A. \& Akgül, O. (2007). Postcards as affective image makers: An idle agent in destination marketing. Tourism Management, 28 (3), 714-725.

Zhang,H., Fu, X, Cai, A. \& Lu, L. (2014). Destination image and tourist loyalty: A meta-analysis. Tourism Management, 40, 213-223.

Zhu, Q. (2011). The effect of destination image on tourists' revisit intention: A case of Feng Huang Ancient Town. Unpublished thesis. Changsha, China: $\mathrm{Hu}$ Nan Normal University. 